\title{
Awareness and Performance of Agricultural Development Schemes in Context of Farmers' Welfare in Haryana
}

\author{
Aditya Shehrawat ${ }^{1}$, Nidhi Sharma ${ }^{2}$, Pardip Shehrawat ${ }^{2}$ and Sandeep Bhakar ${ }^{3}$ \\ ${ }^{1} \mathrm{COA}, \mathrm{CCS}$ HAU, Hisar, India \\ ${ }^{2}$ Department of Extension Education, CCSHAU, Hisar, Haryana, India \\ ${ }^{3}$ Director Extension Specialist (Ext. Education), CCSHAU, Hisar, Haryana, India \\ *Corresponding author: nidhisharma1260@gmail.com (ORCID ID: 0000-0001-9246-2090)
}

Received: $25-12-2019$

Revised: $14-04-2020$

Accepted: 21-05-2020

\begin{abstract}
The Government of India have introduced the innovative schemes of crop insurance however; most of the farmers are unaware of it. Therefore, it is necessary to check the awareness and performance of farmers about crop insurance and agricultural development schemes in Hisar and Fatehabad districts of Haryana state. Data was collected via interview schedule from 100 farmers selected randomly from these two districts. The study revealed that 86 per cent of the farmers were found aware about the crops included under Pradhan Mantri Fasal Beema Yojana (PMFBY) followed by premium paid for insurance of the crops (72\%). The data regarding awareness of Pradhan Mantri Krishi Sinchai Yojana (PMKSY) showed that more than half of the respondents had aware about PMKSY. However, majority of respondents (above $64 \%$ ) were found not aware about subsidy pattern under scheme and additional benefits for small farmers. Performance of agricultural development schemes predicts that majority of the respondent $(87 \%)$ viewed that is performing well. Only 13 per cent of the respondents viewed that the scheme is performing not so good. In case of PMKSY, majority of the respondents (72\%) had opinion that the scheme is performing good. About half of the respondents (52\%) viewed that Agricultural Mechanization for In-Situ Crop Residue Management is performing good. The awareness regarding promotion of Agricultural Mechanization for In-Situ Crop Residue Management (CRM) indicated that two-third respondents had awareness about the scheme and 62 per cent of them agreed that custom hiring centre established under the scheme.

Highlights

(0 The main problem is to check the awareness and performance of farmers about crop insurance and agricultural development schemes in Hisar and Fatehabad districts of Haryana state.
\end{abstract}

Keywords: Awareness, crop insurance scheme, performance, Pradhan Mantri Fasal Bima Yojana

Agriculture is the largest and most important sector of the Indian economy. Nearly 70 percent of population are depending upon agriculture for their livelihood and employment. Farm agricultural development is essential to overall economic progress. Due to Dependence on weather and biological uncertainties in managing crops, the agriculture production fluctuates in India and thus has direct impact on both the national income and the farmers or the cultivators (Nidhi Shanker, 2018). The risk burden of the farmers can be reduced through crop insurance, which is primarily a way of protecting farmers against the element of chance in crop production. Due to the natural calamities the agricultural production, gross national product and also the income of the farmers decrease. The sector is facing manifold problems such as crop failures, non-remunerative prices for crops and poor returns on yield. Agrarian distress is so severe, that it is

\footnotetext{
How to cite this article: Shehrawat, A., Sharma, N., Shehrawat, P. and Bhakar, S. (2020). Awareness and performance of agricultural development schemes in context of farmers' welfare in Haryana. Economic Affairs, 65(2): 167-172.
}

Source of Support: None; Conflict of Interest: None 
pushing many farmers to despair about 39 percent of the cases of farmer suicides were attributed to bankruptcy and indebtedness in 2015 according to the ADSI report (Accidental Deaths and Suicides in India (Rep). Crop insurance spreads the crop losses over space and time, provides social security to the farmers, helps in maintaining their dignity, offers self-help, encourages large investments in agriculture for improving crop yield and increasing agricultural production (Singh, 2004). It was also reported that almost more than half of the progressive farmers were aware regarding the various aspects of PMFBY but there is a need to make the famers aware about crop/weather insurance through awareness programme (Wahab Zada et al. 2019). To escape from natural calamities and farmer suicides, awareness of crop insurance scheme is essential for the farmers. It helps in stabilization of farm production and income of farming community. It helps in optimal allocation of resources in the production process. But farmers are not willing to take crop insurance because they thinks there may be corruption at the time of compensation, it will be lengthy process and the services of financial institutions are not satisfactory. Rajaram and Chetana (2018) also observed that the farmers are unaware of market related information. Keeping these points in mind, the study was conducted to assess the farmers' awareness towards government agricultural development schemes and the performance of government agricultural development schemes.

\section{METHODOLOGY}

The study was conducted in Hisar and Fatehabad district of Haryana state in 2018-19. Thus, 100 farmers were selected randomly and interviewed from villages namely, Sarsod, Bichpuri, Behbalpur, Badonpatti \& Dhansu of Hisar district and Dangra, Jandli Kalan, Chandrawal, Hasanga \& Gorakhpur of Fatehabad district. The statistical measures like mean, frequency, percentage and rank order, etc. were used to draw meaningful inferences. Aggregate total score were calculated based on calculated score. A weighted mean score was obtained and the maximum weighted mean score so obtained were given the rank $1^{\text {st }}$ and the next subsequent one was given $2^{\text {nd }}$ and so on the descending orders.

\section{RESULTS AND DISCUSSION}

The data presented in Table 1 revealed that more than half of the respondents (58\%) belonged to the middle age group (31-50 years) followed by young (up to 30 years) to the extent of 28 per cent. The remaining 14 per cent of the respondents belonged to old age group (51 years and above). Desai also found more than half of groundnut growers (57\%) belonged to middle age group.

Table 1: Personal profile of respondents $(n=100)$

\begin{tabular}{|c|c|c|c|c|}
\hline $\begin{array}{l}\text { S1. } \\
\text { No. }\end{array}$ & Variables & Category & Frequency & Percentage \\
\hline \multirow[t]{3}{*}{1} & \multirow[t]{3}{*}{ Age } & Young (up to 30) & 28 & 28.00 \\
\hline & & $\begin{array}{l}\text { Middle (31-50 } \\
\text { years) }\end{array}$ & 58 & 58.00 \\
\hline & & $\begin{array}{l}\text { Old (51 and } \\
\text { above) }\end{array}$ & 14 & 14.00 \\
\hline \multirow[t]{7}{*}{2} & \multirow[t]{7}{*}{ Education } & Illiterate & 06 & 06.00 \\
\hline & & Primary & 12 & 12.00 \\
\hline & & Middle & 18 & 18.00 \\
\hline & & Matriculation & 32 & 32.00 \\
\hline & & $\begin{array}{l}\text { Higher } \\
\text { secondary }\end{array}$ & 24 & 24.00 \\
\hline & & Graduate & 06 & 06.00 \\
\hline & & Post graduate & 02 & 02.00 \\
\hline \multirow[t]{6}{*}{3} & \multirow{6}{*}{$\begin{array}{l}\text { Land } \\
\text { holding }\end{array}$} & Landless & 00 & 00.00 \\
\hline & & Less than 1 acre & 06 & 06.00 \\
\hline & & $\begin{array}{l}\text { Above } 1 \text { and up } \\
\text { to } 5 \text { acres }\end{array}$ & 42 & 42.00 \\
\hline & & $\begin{array}{l}\text { Above } 5 \text { and up } \\
\text { to } 10 \text { acres }\end{array}$ & 36 & 36.00 \\
\hline & & $\begin{array}{l}\text { Above } 10 \text { to } 15 \\
\text { acres }\end{array}$ & 12 & 12.00 \\
\hline & & Above 15 acres & 04 & 04.00 \\
\hline
\end{tabular}

The data also reported that about one-third of respondents (32\%) were matriculate followed by 24 per cent, 18 per cent, 12 per cent, 6 per cent, 2 per cent higher secondary, middle, primary, graduate and illiterate, respectively. Only 2 per cent of the respondents having post graduate educational qualification.

As for as land holding of respondents is concerned, maximum respondents i.e. 48 per cent were having land up to 5 acres. About one-third of the respondents (36\%) were having land holding ranged from 5 to10 acres. The remaining 16 per cent respondents possess land holding more than 10 acres. 
Table 2: Distribution according to owned farm implements by the farmers $\left(n=100^{*}\right)$

\begin{tabular}{|c|c|c|c|}
\hline Sl. No. & Farm implements & Frequency & Percentage \\
\hline 1 & Tractor & 38 & 38.00 \\
\hline 2 & Harrow & 36 & 36.00 \\
\hline 3 & Cultivator & 32 & 32.00 \\
\hline 4 & Seed cum fertilizer drill & 28 & 28.00 \\
\hline 5 & Laser land leveler & 04 & 04.00 \\
\hline 6 & Combine harvester & 02 & 02.00 \\
\hline 7 & Puddler & 12 & 12.00 \\
\hline 8 & Rotavator & 24 & 24.00 \\
\hline 9 & Happy seeder & 04 & 04.00 \\
\hline 10 & Sprayer (Knap Sack) & 88 & 88.00 \\
\hline 11 & $\begin{array}{l}\text { Tractor mounted spray } \\
\text { pump }\end{array}$ & 24 & 24.00 \\
\hline 12 & Straw Reaper & 06 & 06.00 \\
\hline
\end{tabular}

${ }^{*}$ Mutliple responses.

The data in table 2 represents that about one-third of the respondents (38\%) owned tractor followed by harrow $(36 \%)$, cultivator (32\%), seed cum fertilizer drill (28\%), rotavator $(24 \%)$, tractor mounted spray pump (24\%), and puddler (12\%), respectively. The table 2 also showed that only 4 per cent respondents owned happy seeder, 6 per cent straw reaper, 4 per cent laser land leveller and 2 per cent combine harvester. A majority of respondents (88 per cent) owned knap-sack sprayer.

Table 3: Irrigation facilities available with the respondents $\left(\mathrm{n}=100^{*}\right)$

\begin{tabular}{llll}
\hline $\begin{array}{l}\text { Sl. } \\
\text { No. }\end{array}$ & Modes of irrigation & Frequency(s) & Percentage(s) \\
\hline 1 & Submersible pump & 56 & 56.00 \\
2 & Tube Well & 38 & 38.00 \\
3 & Canal & 85 & 85.00 \\
\hline
\end{tabular}

${ }^{*}$ Mutliple responses

Table 4: Distribution of respondents according to their farming system $(n=100)$

\begin{tabular}{llll}
\hline S1. No. & Farming system & Frequency & Percentage \\
\hline 1 & Livestock & 88 & 88.00 \\
2 & Bee keeping & 04 & 04.00 \\
3 & Agro-Forestry & 08 & 08.00 \\
4 & Organic farming & 03 & 03.00 \\
5 & Mushroom cultivation & 02 & 02.00 \\
6 & Polyhouse vegetable & 04 & 04.00 \\
& production & & \\
7 & Integrated farming & 02 & 02.00 \\
& system & & \\
\hline
\end{tabular}

The data in table 3 revealed that more than half of the respondents (56\%) had irrigation facilities of submersible pump followed by tube well (38 \%). A total of 85 per cent of the farmers were using canal water for irrigation.

\section{Multiple response}

The data in table 4 revealed that majority of respondents (88\%) were doing livestock practices followed by agro-forestry (8 \%), bee keeping (4\%), polyhouse vegetable production $(4 \%)$, organic farming (3\%), integrated farming system (2\%) and mushroom cultivation (2\%), respectively in their farming system.

Table 5: Cropping Pattern and crop rotation $(n=100)$

\begin{tabular}{|c|c|c|c|c|c|c|}
\hline $\begin{array}{l}\dot{0} \\
\dot{\mathbf{z}}\end{array}$ & 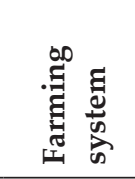 & 冚 & 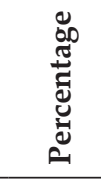 & 宓 & 它 & 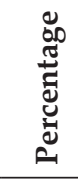 \\
\hline \multirow[t]{5}{*}{1} & \multirow{5}{*}{$\begin{array}{l}\text { Multiple } \\
\text { cropping }\end{array}$} & \multirow[t]{5}{*}{100} & \multirow[t]{5}{*}{100.00} & Paddy-Wheat & 48 & 48.00 \\
\hline & & & & Cotton-Wheat & 30 & 30.00 \\
\hline & & & & $\begin{array}{l}\text { Wheat-Summer } \\
\text { moong-Paddy }\end{array}$ & 08 & 08.00 \\
\hline & & & & $\begin{array}{l}\text { Bajra/Guar/Jowar- } \\
\text { Mustard/ Wheat }\end{array}$ & 12 & 12.00 \\
\hline & & & & $\begin{array}{l}\text { Paddy-other crops } \\
\text { (Veg.) }\end{array}$ & 02 & 02.00 \\
\hline
\end{tabular}

The data in table 5 indicated that all the respondents $(100 \%)$ using multiple cropping system at their farms. As for as crop rotation is concerned, about half of the respondents (48\%) had paddy-wheat crop rotation followed by cotton-wheat (30\%), bajra/guar/jowar/mustard/wheat (12\%) and wheatsummer moong-paddy (8\%), respectively. Only 2 per cent of the respondents were using paddy-other crops (veg. crops) at their farms.

It is indicated from the table 6 that viewing of Television ranked first with weighted mean score of 1.68 followed by reading newspaper ranked second, listening radio ranked third, online solution ranked fourth, reading magazines ranked fifth and visit of Kisan Sewa Kendra ranked sixth with weighted mean score of 1.01, 0.68, 0.30, 0.20 and 0.13 , respectively for seeking information.

It is revealed from the table 7 that among the extension contact of farmers, the most popular were the progressive farmers with weighted mean score 
Table 6: Mass Media Exposure $(\mathrm{n}=100)$

\begin{tabular}{|c|c|c|c|c|c|c|c|c|}
\hline \multirow{2}{*}{ Sl. No. } & \multirow{2}{*}{ Mass media } & \multirow{2}{*}{ Used } & \multicolumn{3}{|c|}{ Extent of utilization } & \multirow{2}{*}{$\begin{array}{r}\text { Total } \\
\text { score }\end{array}$} & \multirow{2}{*}{$\begin{array}{l}\text { Weighted } \\
\text { mean score }\end{array}$} & \multirow{2}{*}{$\begin{array}{l}\text { Rank } \\
\text { order }\end{array}$} \\
\hline & & & Daily (3) & Often (2) & Sometimes (1) & & & \\
\hline 1 & Radio & $40(40.00)$ & $04(12)$ & $20(40)$ & $16(16)$ & 68 & 0.68 & III \\
\hline 2 & $\mathrm{TV}$ & $78(78.00)$ & $34(102)$ & $22(44)$ & $22(22)$ & 168 & 1.68 & I \\
\hline 3 & Newspaper & $40(40.00)$ & $23(69)$ & $15(30)$ & $02(2)$ & 101 & 1.01 & II \\
\hline 4 & Magazines & $10(10.00)$ & $02(6)$ & $06(12)$ & $02(2)$ & 20 & 0.20 & $\mathrm{~V}$ \\
\hline 5 & Kisan Sewa Kendra & $06(06.00)$ & $02(6)$ & $03(6)$ & $01(1)$ & 13 & 0.13 & VI \\
\hline 6 & Online solution & $14(14.00)$ & $05(15)$ & $06(12)$ & $03(3)$ & 30 & 0.30 & IV \\
\hline
\end{tabular}

Table 7: Extension contact $(\mathrm{n}=100)$

\begin{tabular}{|c|c|c|c|c|c|c|c|c|}
\hline \multirow[b]{2}{*}{ Sl. No. } & \multirow[b]{2}{*}{ Extension Official } & \multicolumn{4}{|c|}{ Frequency of contact } & \multirow[b]{2}{*}{$\begin{array}{l}\text { Total } \\
\text { score }\end{array}$} & \multirow[b]{2}{*}{$\begin{array}{l}\text { Weighted } \\
\text { mean score }\end{array}$} & \multirow[b]{2}{*}{$\begin{array}{l}\text { Rank } \\
\text { order }\end{array}$} \\
\hline & & Weekly (4) & Fortnightly (3) & Monthly (2) & $\begin{array}{l}\text { Whenever } \\
\text { Needed (1) }\end{array}$ & & & \\
\hline 1 & $\mathrm{ADO}$ & $15(60)$ & $20(60)$ & $22(44)$ & $38(38)$ & 202 & 2.02 & II \\
\hline 2 & SDAO/SMS & $8(32)$ & $18(54)$ & $10(20)$ & $52(52)$ & 158 & 1.58 & III \\
\hline 3 & Scientists & $8(32)$ & $12(36)$ & $06(12)$ & $44(44)$ & 124 & 1.24 & IV \\
\hline 4 & Progressive farmers & $26(104)$ & $15(45)$ & $19(38)$ & $38(38)$ & 225 & 2.25 & I \\
\hline 5 & Others & $02(8)$ & $4(12)$ & $6(12)$ & $62(62)$ & 94 & 0.94 & V \\
\hline
\end{tabular}

2.25. ADO and SDAO/SMS ranked second and third with weighted mean score of 2.02 and 1.58 followed by scientists and others ranked at fourth and fifth with weighted mean score 1.24, 0.94, respectively.

The data regarding farmers' awareness about agricultural development schemes presented in table 8 predict that 86 per cent of the farmers were aware about the crops included under PMFBY followed by 72 per cent had awareness about the premium paid for insurance of the crops. 89 per cent of the respondents had knowledge that PMFBY is mandatory for loanee farmers. The data regarding awareness of PMKSY showed that more than half of the respondents had awareness about PMKSY. However, large majority the respondents (above 64 $\%$ ) were not aware about subsidy pattern, sealing of area under scheme and additional benefit for small and marginal farmers.

Seventy two per cent of respondents were not aware about e-NAM facility. In case of ATMA scheme, majority of the respondents $(72 \%)$ were aware about the scheme and 68 per cent were aware about its implementing agency at district level. . More than half of the respondents had awareness about NFSM. The data regarding awareness of Mission on Integrated Development of Horticulture (MIDH Sub component-NHM) revealed that 53 per cent of the respondents were aware about MIDH. 40 per cent of them know about the components covered under the scheme. About one-third (36\%) of the respondents had awareness about subsidy pattern being followed for the components covered under the scheme.

As for as soil health card scheme is concerned, the respondents had awareness to the extent of 68 per cent. More than half of the respondents (56\%) know about the benefits of the scheme.

The awareness regarding promotion of Agricultural Mechanization for In-Situ Crop Residue Management (CRM) presented in table 8 indicated that two-third respondents had awareness about the scheme and 62 per cent of them knows that custom hiring centre established under the scheme. More than half of the respondent (58\%) knows about the assistance being provided by the government on farm machineries under the scheme for crop residue management. A total of 65 per cent of the respondents were aware that trainings /extension programmes are organized under the scheme.

Majority of the sampled farmers/respondents were not aware about Prampragat Krishi Vikas Yojana (PKVY) and Small Farmers Agri-business Consortium (SFAC). Only few (less than 15\%) were aware about the PKVY \& SFAC. 
Table 8: Farmers' Awareness about Agricultural Development Schemes $\left(\mathrm{n}=100^{*}\right)$

\begin{tabular}{|c|c|c|c|c|c|}
\hline \multirow{3}{*}{ S1. No. } & \multirow{3}{*}{ Statements } & \multicolumn{4}{|c|}{ Degree of Awareness } \\
\hline & & \multicolumn{2}{|c|}{ Aware } & \multicolumn{2}{|c|}{ Not Aware } \\
\hline & & $\mathrm{f}$ & $\%$ & $\mathrm{f}$ & $\%$ \\
\hline 1 & Pradhan Mantri Fasal Beema Yojana & & & & \\
\hline$\overline{\text { (a) }}$ & Awareness about crops included under the scheme & 86 & 86.00 & 14 & 14.00 \\
\hline (b) & Awareness about premium of crops & 72 & 72.00 & 28 & 28.00 \\
\hline (c) & Knowledge that PMFBY is mandatory for Loanee farmers & 89 & 89.00 & 11 & 11.00 \\
\hline 2 & Pradhan Mantri Krishi Sinchai Yojana (Per Drop More Crops) & & & & \\
\hline$\overline{\text { (a) }}$ & Awareness about PMKSY & 56 & 56.00 & 44 & 44.00 \\
\hline (b) & Awareness about subsidy pattern for micro irrigation & 35 & 35.00 & 65 & 65.00 \\
\hline (c) & Knowledge about sealing of area under the scheme for availing benefits & 32 & 32.00 & 68 & 68.00 \\
\hline (d) & $\begin{array}{l}\text { Knowledge about additional benefits for Small \& marginal farmers under the } \\
\text { scheme }\end{array}$ & 36 & 36.00 & 64 & 64.00 \\
\hline 3 & Awareness about e-NAM facility & 28 & 28.00 & 72 & 72.00 \\
\hline 4 & Agricultural Technology Management Agency (ATMA) & & & & \\
\hline$\overline{\text { (a) }}$ & Awareness about ATMA scheme & 72 & 72.00 & 28 & 28.00 \\
\hline (b) & Awareness about implementing agency & 68 & 68.00 & 32 & 32.00 \\
\hline 5 & National Food Security Mission (NFSM) & & & & \\
\hline (a) & Awareness about NFSM scheme & 58 & 58.00 & 42 & 42.00 \\
\hline (b) & Awareness about implementing agency & 52 & 52.00 & 48 & 48.00 \\
\hline 6 & Mission on Integrated Development of Horticulture (MIDH Sub component- & HM) & & & \\
\hline (a) & Awareness about MIDH & 53 & 53.00 & 47 & 47.00 \\
\hline (b) & Awareness about implementing agency & 48 & 48.00 & 52 & 52.00 \\
\hline (c) & Awareness about the components of the scheme & 40 & 40.00 & 60 & 60.00 \\
\hline (d) & Awareness about subsidy pattern under the scheme & 36 & 36.00 & 64 & 64.00 \\
\hline 7 & Soil Health Card Scheme & & & & \\
\hline (a) & Awareness about SHC & 68 & 68.00 & 32 & 32.00 \\
\hline (b) & Awareness about benefit of SHC & 56 & 56.00 & 44 & 44.00 \\
\hline 8 & Promotion of Agricultural Mechanization for In-Situ Crop Residue Managem & & & & \\
\hline (a) & Awareness about the scheme & 70 & 70.00 & 30 & 30.00 \\
\hline (b) & Knowledge about Custom Hire Centre & 62 & 62.00 & 38 & 38.00 \\
\hline (c) & $\begin{array}{l}\text { Knowledge that assistance is being provided on farm Machinery under the } \\
\text { scheme }\end{array}$ & 58 & 58.00 & 42 & 42.00 \\
\hline (d) & Awareness about programmes/trainings organized under the scheme & 65 & 65.00 & 35 & 35.00 \\
\hline 9 & Prampragat Krishi Vikas Yojana (PKVY) & & & & \\
\hline$\overline{\text { (a) }}$ & Awareness about the scheme & 36 & 36.00 & 64 & 64.00 \\
\hline (b) & Awareness about implementing agency & 32 & 32.00 & 68 & 68.00 \\
\hline (c) & Awareness about purpose of scheme & 28 & 28.00 & 72 & 72.00 \\
\hline (d) & $\begin{array}{l}\text { Knowledge about assistance given for promotion of organic farming under the } \\
\text { scheme }\end{array}$ & 16 & 16.00 & 84 & 84.00 \\
\hline 10 & Small Farmers Agri-business Consortium (SFAC) & & & & \\
\hline (a) & Awareness about the scheme & 32 & 32.00 & 68 & 68.00 \\
\hline (b) & Awareness about implementing agency & 26 & 26.00 & 74 & 74.00 \\
\hline (c) & Awareness about purpose of scheme & 14 & 14.00 & 86 & 86.00 \\
\hline
\end{tabular}

${ }^{*}$ Multiple responses.

The data in table 9 regarding performance of agricultural development schemes predict that majority of the respondent $(87 \%)$ is of view that Pradhan Mantri Fasal Beema Yojana is performing well. Only 13 per cent of the respondents viewed that the scheme is performing not so good. In case of Pradhan Mantri Krishi Sinchai Yojana (Per Drop More Crops) is concerned, majority of the respondents $(72.00 \%)$ had opinion that the scheme is performing good. The poor performance was observed in case of e-NAM facility provided by the government as 85 per cent of the respondents 
Table 9: Perception of respondents towards performance of Agricultural Development Schemes $\left(\mathrm{n}=100^{*}\right)$

\begin{tabular}{|c|c|c|c|c|c|}
\hline \multirow{3}{*}{ S1. No. } & \multirow{3}{*}{ Statements } & \multicolumn{4}{|c|}{ Degree of Performance } \\
\hline & & \multicolumn{2}{|c|}{ Good } & \multicolumn{2}{|c|}{ Not so good } \\
\hline & & Frequency & Percentage & Frequency & Percentage \\
\hline 1 & Pradhan Mantri Fasal Beema Yojana & 87 & 87.00 & 13 & 13.00 \\
\hline 2 & Pradhan Mantri Krishi Sinchai Yojana (Per Drop More Crops) & 72 & 72.00 & 28 & 28.00 \\
\hline 3 & e-NAM & 15 & 15.00 & 85 & 85.00 \\
\hline 4 & Agricultural Technology Management Agency (ATMA) & 64 & 64.00 & 36 & 36.00 \\
\hline 5 & National Food Security Mission (NFSM) & 52 & 52.00 & 48 & 48.00 \\
\hline 6 & $\begin{array}{l}\text { Mission on Integrated Development of Horticulture (MIDH } \\
\text { Sub component-NHM) }\end{array}$ & 50 & 50.00 & 50 & 50.00 \\
\hline 7 & Soil Health Cards & 38 & 38.00 & 62 & 62.00 \\
\hline 8 & $\begin{array}{l}\text { Agricultural Mechanization for } \mathrm{In} \text {-Situ Crop Residue } \\
\text { Management (CRM) }\end{array}$ & 52 & 52.00 & 48 & 48.00 \\
\hline 9 & Prampragat Krishi Vikas Yojana (PKVY) & 12 & 12.00 & 88 & 88.00 \\
\hline 10 & Small farmers Agri-business Consortium (SFAC) & 16 & 16.00 & 84 & 84.00 \\
\hline
\end{tabular}

${ }^{*}$ Multiple responses.

viewed that performance is not so good.

The data in table 9 also indicates that 64 per cent, 52 percent and 50 percent of the respondents viewed that ATMA, NFSM and MIDH schemes respectively performing good. About half of the respondents (52\%) viewed that the scheme for promotion of Agricultural Mechanization for In-Situ Crop Residue Management is performing good. Majority of the sampled farmers viewed that the schemes like Prampragat Krishi Vikas Yojana (PKVY), Small farmers Agri-business Consortium (SFAC) and Soil Health Cards are performing not so good.

\section{CONCLUSIONS}

It is concluded that 86 per cent of the farmers were aware about the crops included under PMFBY followed by 72 per cent had awareness about the premium paid for insurance of the crops. Seventy two per cent of respondents were not about e-NAM facility. As for as soil health card scheme is concerned, the respondents had awareness to the extent of 68 per cent. More than half of the respondents (56\%) know about the benefits of the scheme. Regarding performance of agricultural development schemes; majority of the respondents were of view that Pradhan Mantri Fasal Beema Yojana, Pradhan Mantri Krishi Sinchai Yojana (Per Drop More Crops) is performing good. 64 percent, 52 percent and 50 percent of the respondents viewed that ATMA, NFSM and MIDH schemes respectively are also performing good.

\section{REFERENCES}

Accidental Deaths and Suicides in India (Rep.). (n.d.). National Crime Records Bureau. Retrieved February 20, 2019, from http://ncrb.gov.in/

Desai, B.R. 1985. A study of groundnut growers in Sindhudurg districts. M.Sc. Thesis, Punjab Agricultural University, Ludhiana, India. Economic Affairs, 64(3): 503-512.

Kumar, A., Doharey, R.K., Kumar, M., Singh, S.N., Kumar, M. and Sai, A.K. 2017. Knowledge and adoption extent of farmers about crop insurance scheme in Etawah district (U.P.). Journal of Pharmacognosy and Phytochemistry, 6(3): 154-156.

Nidhi Shanker. 2018. Agricultural Insurance - The Need of the Hour. Scholarly Research Journal for Interdisciplinary Studies, 5(44): 10432-10438.

Rajaram, Y. and Chetana, B.S. 2018. A Study on Awareness Level on Crop Insurance Schemes and the Factors Influencing Choice of Information Sources among Farmers. International Journal of Marketing $\mathcal{E}$ Financial Management, 6(1): 01-08.

Ruchbah Rai. 2019. Pradhan Mantri Fasal Bima Yojana: An Assessment of India's Crop Insurance Scheme", ORF Issue Brief No. 296, Observer Research Foundation.

Singh, S. 2004. Crop Insurance in India-A Brief Review. Journal of the Indian Society of Agricultural Statistics, 57 (special Issue), pp 217-225. Retrieved December 10, 2012 from http://www.isas.org.in/jsp/volume/vol57/Shivtar\%20 Singh.pdf

Wahab, Z.A.M., Mohapatra, L. and Anand, A. 2019. Analysis of Awareness Level of Agricultural Insurance among the Stakeholders in Punjab. Economic Affairs, 64(3): 503-512. 